Int. J. Dev. Biol. 57: 891-895 (2013)

doi: $10.1387 / \mathrm{ijdb} .130192 \mathrm{rp}$

\title{
Sexual dimorphism of AMH, DMRT1 and RSPO1 localization in the developing gonads of six anuran species
}

\author{
RAFAL P. PIPREK ${ }^{*, 1}$, ANNA PECIO ${ }^{1}$, KATARZYNA LASKOWSKA-KASZUB', ${ }^{2,3}$ \\ JACEK Z. KUBIAK ${ }^{2,3}$ and JACEK M. SZYMURA ${ }^{1}$ \\ ${ }^{1}$ Department of Comparative Anatomy, Institute of Zoology, Jagiellonian University, Krakow, Poland, \\ ${ }^{2}$ CNRS, UMR 6290, Institute of Genetics and Development of Rennes, Cell Cycle Group, France and \\ ${ }^{3}$ Université Rennes 1, UEB, UMS Biosit, Faculty of Medicine, Rennes, France
}

\begin{abstract}
In vertebrates, several genes which are differentially expressed in various species, have been implicated in sex determination and gonadal differentiation. We used immunolocalization to study the expression pattern of three proteins AMH, DMRT1, RSPO1 involved in the sexual differentiation of gonads. The pattern of AMH, DMRT1 and RSPO1 expression was analyzed in $X$. laevis and in five other divergent anuran species: Bombina bombina, Bufo viridis, Hyla arborea, Rana arvalis and Rana temporaria during gonadal development. The pattern of expression of AMH in the developing testes of six studied anuran species was similar to that described for other vertebrates. AMH was strongly expressed in differentiating Sertoli cells. Interestingly, in B. viridis, $\boldsymbol{R}$. arvalis and $\boldsymbol{R}$. temporaria, AMH was also expressed in ovaries. In all studied species, DMRT1 was highly expressed in the developing testes, in both the somatic and germ cells. It was also expressed at low level in ovaries in all studied species, with the exception of $\boldsymbol{H}$. arborea. RSPO1 was expressed in the developing ovaries, especially in the somatic cells, and was almost undetectable in developing testes in all examined anurans. These developmental expression patterns strongly suggest an involvement of AMH and DMRT1 in the development of male gonads and of RSPO1 in the female gonads. The differences in the expression patterns of these proteins in the gonads of different species might reflect the diversity of gonadal development patterns in anurans resulting from long lasting and diverged paths of their evolution.
\end{abstract}

KEY WORDS: AMH, DMRT1, RSPO1, sex differentiation, amphibian

The differentiation of the gonads into the ovaries or testes depends on the expression of sex determining genes. Due to their expression in the developing ovary, the germ cells differentiate into oogonia surrounded by follicular cell precursors (Witschi, 1929). In males, differentiating Sertoli cells enclose the germ cells, forming the testis cords. Within the cords, male germ cells transform into spermatogonia. In majority of vertebrates, the differentiating Sertoli cells express the AMH (anti-Müllerian hormone). The AMH belongs to the TGF family and is a growth factor which acts as a paracrine or endocrine factor (Cate et al., 1986; Behringer et al., 1994). In the fetal testes, AMH is produced in Sertoli cells from where it diffuses and promotes cell apoptosis in Müllerian ducts leading to their degeneration in males. Moreover, $\mathrm{AMH}$ is expressed in the granulosa cells in the ovarian follicles, inhibiting the growth of the latter (Vigier et al., 1984). The expression pattern of $\mathrm{AMH}$ has never been described in amphibians (Dumond et al., 2008).

Dmrt1 (doublesex and mab-3 related transcription factor 1 ) is another gene involved in male sex development in vertebrates and invertebrates (Raymond et al., 1998; Smith et al., 2009). The DMRT1 protein is a transcription factor and contains a zinc finger DNA-binding domain (DM domain) (Raymond et al., 1998). In vertebrates, a null-mutation in Dmrt1 results in partial or complete sex reversal, and some studies imply the existence of interspecific differences in the function of DMRT1 (Raymond et

Abbreviations used in this paper: AMH, anti-Müllerian hormone; DMRT1, doublesex and mab-3 related transcription factor 1; RSPO1, R-spondin 1.

\footnotetext{
*Address correspondence to: Rafał P. Piprek. Department of Comparative Anatomy, Institute of Zoology UJ, Gronostajowa 9, 30-387 Kraków, Poland. Tel: +481-2664-5059. e-mail: rafal.piprek@uj.edu.pl
}

Supplementary Material (tables and figures) for this paper is available at: http://dx.doi.org/10.1387/ijdb.130192rp 
al., 1999; Smith et al., 1999). In all examined vertebrates Dmrt1 is expressed in precursors of Sertoli cells associated with developing male gonads and participates in male sex determination and/or differentiation.

The main agents involved in female sex determination in mice are the growth factors WNT4 and RSPO1 (Bernard and Harley, 2007; Chassot et al., 2008; Piprek, 2009). WNT4 inhibits $\beta$-catenin degradation allowing it to migrate into the nucleus and influences gene expression. The secreted factor RSPO1 amplifies the WNT signaling by stabilizing $\beta$-catenin intercellulary (Kim et al., 2006). Its null-mutation in human causes complete female-to-male sex determination indicating its primary role in sex determination (Parma et al., 2006). In mouse or chicken, RSPO1also participates in ovarian development (Chassot et al., 2008; Smith et al., 2008).

Sex determining genes have been well studied especially in mice, however, remain obscure in other vertebrates. In amphibians, the expression of Dmrt1 was examined by RT-PCR in Xenopus laevis (Osawa et al., 2005; Shibata et al., 2002) and in Bufo marinus (Abramyan et al., 2009), and by immunolocalization in $R$. rugosa (Aoyma et al., 2003). To obtain a broad perspective on the immunolocalization of chosen genes in Anura and their potential relation to sexual development, we included species of two basal lineages, Bombinatoridae (Bombina bombina) and Pipidae (Xenopus laevis) as well as species belonging to two most derived sister clades Bufonoidea (Hyla arborea, Bufo viridis) and Ranoidea (Rana temporaria, Rana arvalis) (Roelants et al., 2007). These species differ in their heterogametic status and developmental timing of gonad differentiation pathway.

\section{Results}

\section{Amino acid sequence and antibody specificity}

To evaluate the specificity of antibodies used in our study to identify anuran proteins we compared the amino acid sequences of human proteins AMH, DMRT1 and RSPO1 with sequences from GenBank database (Supp. Table S1).

\section{Immunohistochemical analysis $A M H$}

The AMH presence in the gonads was dependent on the developmental stage and sex of the gonad. The signal intensity of $\mathrm{AMH}$ immunolocalization is presented in Supp. Table S2. In $X$. laevis $\mathrm{AMH}$ was hardly detectable in the undifferentiated gonads (Neuwkoop stage 47-50, Fig.1A). At Neuwkoop stage 52, a strong signal of AMH was observed in somatic and germ cells of the differentiating testis (Fig.1B). However, the highest signal was evident in the somatic cells within the testis cords,

Fig. 1. Immunolocalization of AMH (A-C), DMRT1 (E-G) and RSPO1 (H-J) in the undifferentiated gonads, testes and ovaries in Xenopus laevis. $D$, control. The gonads are pointed out with arrows. o, oogonial cells; so, somatic cells; ts, testis cords. Scale bar $40 \mu \mathrm{m}$. which correspond to the differentiating Sertoli cells. AMH was not detected in developing ovaries (Fig.1C).

In the rest studied anuran species AMH signal was high in developing testes (Supp. Table S2, Supp. Fig. S1). Slight signal was also visible in the undifferentiated gonads of studied species besides $B$. viridis and $H$. arborea. AMH was also present in the developing ovaries of $B$. viridis, $R$. arvalis and $R$. temporaria, however, the signal was definitely not so intensive as in the testes.

\section{$D M R T 1$}

Immunohistochemical localization of DMRT1 showed that this protein was up-regulated in the male gonads in all studied anuran species (Supp. Table S3). In X. laevis DMRT1 had very low level of expression in undifferentiated gonads (Fig.1E) and the expression increased in the developing testis after Nieuwkoop stage 52 (Fig.1F).DMRT1 was present in the whole male gonads, in both somatic and germ cells. In developing ovary the DMRT1 signal was very weak (almost undetectable; Fig.1G).

In all studied anuran species, DMRT1 signal was highest in the developing testes (Supp. Fig. S2). It was also visible in the undifferentiated gonads of $R$. arvalis and $R$. temporaria and in the developing ovaries in all studied species but not in $X$. laevis and $H$. arborea.

\section{$R S P O 1$}

Immunohistochemical studies using antibodies anti-RSPO1 revealed presence of RSPO1 protein in mesonephroi and gonads of all studied species with the strong up-regulation during the ovarian development (Supp. Table S4). In X. laevis RSPO1 was undetectable in the undifferentiated gonad (Fig.1H). Its signal slightly increased during testis differentiation (Fig.1I). In contrast in developing ovaries (from Nieuwkoop stage 52) a strong signal was observed in the cortex and medulla in the oogonial cells and somatic cells (Fig.1J). The strongest signal was visible in somatic cells covering the ovary.
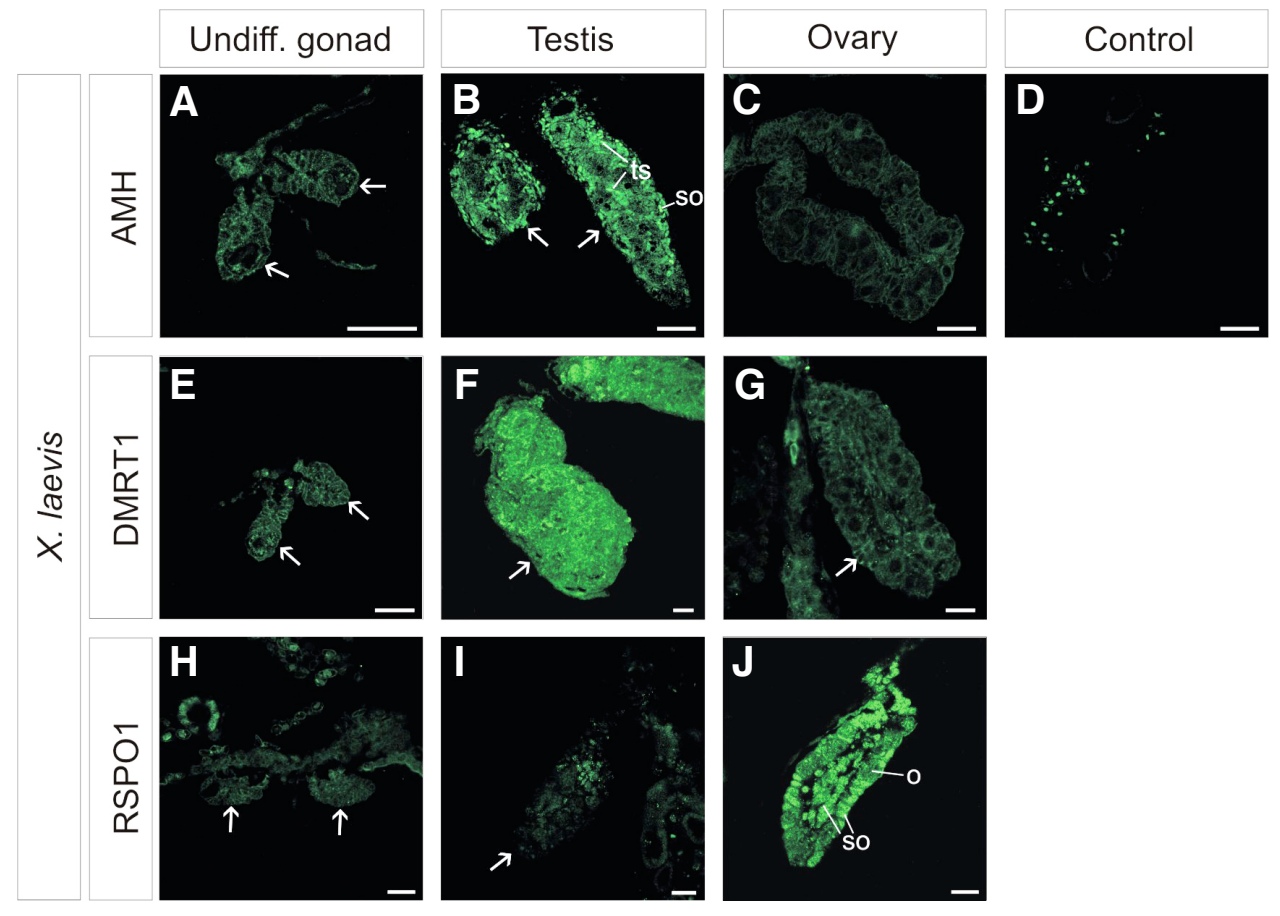
In other anuran species, RSPO1 was not detected in the undifferentiated gonads as in $X$. laevis, moreover, this protein was detected in the germ cells in developing testes in all studied species besides $R$. arvalis and $R$. temporaria (Supp. Fig. S3).

\section{Discussion}

Our study showed that in all examined species AMH, DMRT1 and RSPO1 were expressed in gonads where their expression was sexually dimorphic. The onset of such a sex-dependent expression was established during the sexual differentiation of gonads that overlaps with the period of sex determination. Before this stage, the gonads were undifferentiated and the tested genes potentially involved in sex determination or gonadal differentiation were expressed at undetectable or a very low level.

\section{$\mathbf{A M H}$}

The AMH protein was found in fish, reptiles, birds, marsupials and placental mammals where it is responsible for the disappearance of Müllerian ducts in males (Cate et al., 1986; Josso et al., 1993). A functional $\mathrm{AMH}$ has never been identified in amphibians. Only GenBank database indicated the presence of 'Predicted Müllerian-Inhibiting Factor' (XP_004911480.1) in X. tropicalis genome. However, it was unclear if this protein exists in amphibians. Nevertheless, the sexually dimorphic pattern of this protein localization identified in our study and its up-regulation in the developing testes suggest its homology to AMH of other vertebrates.

In our study the expression of $\mathrm{AMH}$ was highly up-regulated in the male gonads. We observed the expression of $\mathrm{AMH}$ in the somatic cells of the testis cords which are most probably differentiating Sertoli cells. AMH signal, however very low, was also visible in the undifferentiated gonads of anurans, i.e. before sexual differentiation of gonads. The onset of $\mathrm{AMH}$ expression before the sexual differentiation of gonad was frequently observed among vertebrates, e.g. in medaka (Oryzias latipes), and zebrafish (Danio rerio), the red-eared slider (Trachemys scripta), the American alligator (Alligator mississippiensis) and the chicken (De Santa Barbara et al., 1998; Oreal et al., 1998; Arango et al., 1999; Western et al., 1999; Rodriguez-Mari et al., 2005; Klüver et al., 2007); however, in mice AMH is expressed after the onset of testis differentiation (Münsterberg and Lovell-Badge, 1991). Importantly, we also detected the expression of $\mathrm{AMH}$ in ovaries, which has been observed also in other vertebrates, such as mouse, rat, human, zebrafish and medaka, and the role of this protein in germ cells is unknown (Grootegoed et al., 1994; Baarends et al., 1995; Weenen et al., 2004; Klüver et al., 2007; Rodriguez-Mari et al., 2005). In human ovary, AMH functions in initial and cyclic follicle recruitment in follicular cells (Weenen et al., 2004). This suggests that in amphibians, similar to fishes and mammals, $\mathrm{AMH}$ function is not restricted to testis development.

\section{DMRT1}

We showed that the DMRT1 protein was observed in the undifferentiated gonads of anurans at least at a low level and then its concentration increased in both male and female developing gonads and the expression was significantly higher in the testes. The strong signal of DMRT1 was characteristic for both the somatic and germ cells of the developing testes. Previous studies showed that DMRT1 was observed in the Sertoli and interstitial cells in the testes of the frog Rana rugosa as in our study, but it was not detected in undifferentiated gonads or the ovaries of this frog, which is opposite to our findings in other anuran species (Shibata et al., 2002; Aoyma et al., 2003). In Bufo marinus expression of DMRT1 was shown previously for ovaries and testes especially during the sexual differentiation of gonads, however, no data were provided for the undifferentiated gonads (Abramyana et al., 2009). In $X$. laevis DMRT1 and its orthologue DMW were detected in the undifferentiated and then, during the sexual differentiation of gonads, the expression of DMW disappeared and the expression of DMRT1 was maintained in somatic cells of the testis (Yoshimoto et al., 2010). Osawa et al., (2005) showed that in X. laevis theDMRT1 is expressed at a much higher level in testes than in ovaries, which agrees with our findings. Bewick et al., (2010) found that in $X$ laevis, DMRT1 is present in two isoforms and showed that these two isoforms may be located in different sex gonads or may appear at different developmental tags.

The pattern of DMRT1 expression in anurans is similar to its expression in other vertebrates. It was observed in the testes and ovaries of zebrafish with the higher expression in the male gonads (Guo et al., 2005), whereas in the rainbow trout (Oncorhynchus mykiss) DMRT1 was expressed only in the male gonad (Marchand et al., 2000). In reptiles such as the red-eared slider, the mugger crocodile (Crocodilus palustris) and the American alligator, DMRT1 was detected in the undifferentiated gonads, then was up-regulated in the testis and disappeared in the ovary (Murdock et al., 2003; Anand et al., 2008; Smith et al., 1999). In mammals DMRT1 is equally expressed, at a low level, in the undifferentiated $X X$ and $X Y$ gonads in both somatic and germ cells and then its level rises in the developing testis, in the Sertoli cells and spermatogonia, but it disappears from somatic cells and oocytes in the developing ovaries (Lei et al., 2011). This protein is always present in the male gonads, but in some vertebrates such as Oncorhynchus sp., crocodile, alligator and mouse, it is lost from the ovaries. It can be assumed that DMRT1 is responsible for the differentiation of the Sertoli cells and is involved in the maintenance of the undifferentiated state of the germ cells in all vertebrates including anurans.

\section{RSPO1}

RSPO1 (R-spondin1) is a secreted activator protein encoded by the Rspo1 gene, a member of the R-spondin family (Strausberg et al., 2003). Our study showed a low concentration of this protein in undifferentiated anuran gonads similarly, to the zebrafish, the chicken and the red-eared slider (Smith et al., 2008; Zhang et al., 2011). RSPO1 was significantly up-regulated in the developing ovaries in anuran species studied by us. A sexual dimorphism of RSPO1 expression was very evident and similar to the situation in other vertebrates, the protein displayed a higher concentration in ovaries than in testes. During the sexual differentiation of gonads in anurans, a significant increase in RSPO1 level was observed especially in somatic cells differentiating into follicular cells within the developing ovaries, but also in the oogonial cells. The expression of RSPO1 is high in the developing ovaries in zebrafish, red-eared slider, chicken, goat, mouse and humanespecially in cytosol and nuclei of oogonia, oocytes, granulosa (follicular) and theca cells (Kocer et al., 2008; Smith et al., 2008; Tomaselli et al., 2011; Zhang et al., 2011). Our study shows that the pattern 
of RSPO1 expression is related to the ovarian development and this relation is evolutionary stable among vertebrates.

\section{Conclusions}

The anurans $\mathrm{AMH}$ orthologues detected in this study were expressed in the developing testes of analyzed species, especially in the differentiating Sertoli cells, as well as in many ovarian cells, which is similar to some other vertebrates.DMRT1 expression was higher in the developing testes and characteristic for both the somatic and germ cells, but a low concentration of this protein in some species was also observed in the ovaries. The higher expression of DMRT1 in anuran testes is similar to other vertebrates, implying a conservative role of the protein in the testis development.

RSPO1 was significantly expressed in the developing ovaries of all examined anurans, especially in the somatic cells. This implies the common role of RSPO1 in the ovarian development in vertebrates. In spite of many similarities between the six species, our analysis showed numerous spatiotemporal differences in RSPO1 expression among the gonads of examined anuran species as well as dissimilarities in comparison to other vertebrates. This suggests that different potential roles and regulative interactions between sex-determining genes take place in vertebrate species. It also reflects the long-term, independent evolution of these anurans among which the first branches separated 200-250 MYA (Roelants et al., 2007).

\section{Materials and Methods}

\section{Animals}

Eggs of Hyla arborea, Bufo viridis, Rana temporaria and $R$. arvalis were collected in the wild in the vicinity of Bielsko-Biała (Pogórze Śląskie, Poland) and eggs of Bombina bombinanear Miechów (Wyżyna Miechowska, Poland). Larvae of Xenopus laevis were obtained in the laboratory following in vitro fertilization. All specimens used in the study were acquired according to Polish legal regulations concerning the protection of wild species (Dz. U. nr 33, poz. 289, 2005). We obtained permission from the Polish Ministry of Environment Protection and Forestry and approval from the I Local Commission for Ethics in Experiments on Animals. Tadpoles of $X$. laevis were staged according to Nieuwkoop and Faber (1956) while the other species were staged according to Gosner (1960). Tadpoles were anesthetized with MS-222 solution at the sampling points (Supp. Table S5).

\section{Immunohistochemistry}

Dissected gonads with adjacent tissues (mesonephroi, interregnal glands) were fixed in Bouin's solution and embedded in paraplast (Sigma, Poznan, Poland). Sections were processed as previously described (Piprek et al., 2013). We used rabbit polyclonal antibodies against three human proteins: DMRT1, AMH (both Santa Cruz Biotechnology) or RSPO1 (Abcam) (Supp. Table S1). Goat anti-rabbit secondary antibodies conjugated with AlexaFluor488 (Molecular Probes) in dilution 1:200 were used. The gonadal sex was recognized by the distribution of germ cells (large cells with pale nuclei) and the presence of the cortex and medulla.

\section{Acknowledgments}

We are grateful to Prof. Malgorzata Kloc for discussions and constructing remarks as well as to Dr. M. Pabijan for English correction. We thank the Confocal Microscopy Laboratory, Institute of Zoology, Jagiellonian University for sharing their microscopy facilities and Gérard Fenech for efficient technical support with X. laevis. RPP was supported by a grant from the MNiSzW (N N303 542938) and START stipend from FNP. JZK was supported by a grant from ARC. This publication was supported by funding from the Jagiellonian University within the SET project. The project is co-financed by the European Union.

\section{References}

ABRAMYAN J, EZAZT, GRAVES JA, KOOPMANP (2009). Z and W sex chromosomes in the cane toad (Bufo marinus). Chromosome Res 17: 1015-1024.

ANAND A, PATEL M, LALREMRUATA A, SINGH AP, AGRAWAL R, SINGH L, AGGARWAL RK (2008). Multiple alternative splicing of Dmrt1 during gonadogenesis in Indian mugger, a species exhibiting temperature-dependent sex determination. Gene 425: 56-63.

AOYAMA S, SHIBATA K, TOKUNAGA S, TAKASE M, MATSUI K, NAKAMURA M (2003). Expression of Dmrt1 protein in developing and in sex-reversed gonads of amphibians. Cytogenet Genome Res 101: 295-301.

ARANGO NA, LOVELL-BADGE R, BEHRINGERRR (1999). Targeted mutagenesis of the endogenous mouse Mis gene promoter: in vivo definition of genetic pathways of vertebrate sexual development. Cell 99: 409-419.

BAARENDS WM, UILENBROEK JT, KRAMER P, HOOGERBRUGGE JW, VAN LEEUWEN EC, THEMMEN AP, GROOTEGOED JA (1995). Anti-müllerian hormone and anti-Müllerian hormone type II receptor messenger ribonucleic acid expression in rat ovaries during postnatal development, the estrous cycle, and gonadotropin-induced follicle growth. Endocrinology 136: 4951-4962.

BEHRINGER RR, FINEGOLD MJ, CATE RL (1994). Müllerian-inhibiting substance function during mammalian sexual development. Cell 79: 415-425.

BERNARD P, HERLEY VR (2007).Wnt4 action in gonadal development and sex determination. Int J Biochem Cell Biol 39: 31-43.

BEWICK AJ, ANDERSON DW, EVANS BJ (2011). Evolution of the closely related, sex-related genes DM-W and DMRT1 in African clawed frogs (Xenopus). Evolution 65: 698-712.

CATE RL, MATTALIANO RJ, HESSION C, TIZARD R, FARBER NM, CHEUNG A, NINFA EG, FREY AZ, GASH DJ, CHOW EP, FISHER RA, BERTONIS JM, TORRES G, WALLNER BP, RAMACHANDRAN KL, RAGIN RC, MANGANARO TF, MACLAUGHLIN DT, DONAHOE PK (1986). Isolation of the bovine and human genes for Müllerian inhibiting substance and expression of the human genes in animal cells. Cell 45: 685-698.

CHASSOT AA, RANC F, GREGOIRE EP, ROEPERS-GAJADIEN HL, TAKETO MM, CAMERINO G, DE ROOIJ DG, SCHEDLA, CHABOISSIER MC (2008). Activation of $\beta$-catenin signaling by Rspo1 controls differentiation of the mammalian ovary. Hum Mol Genet 17: 1264-1277.

DE SANTA BARBARA P, BONNEAUD N, BOIZET B, DESCLOZEAUX M, MONIOT B, SUDBECK P, SCHERER G, POULAT F, BERTA P (1998). Direct interaction of SRY-related protein SOX9 and steroidogenic factor 1 regulates transcription of the human anti-Mullerian hormone gene. Mol Cell Biol 18: 6653-6665.

DUMOND H, MAUFROID JP, KO CI, CHARDARD D, CHESNEL A, FLAMENT S (2008). Freemartin in the amphibian Pleurodeles waltl: parabiosis between individuals from opposite sex triggers both germ and somatic cells alterations during female gonad development. Mol Reprod Dev 75: 439-449.

GOSNER KL (1960).A simplified table for staging anuran embryos and larvae with notes on identification. Herpetologica 6: 183-90.

GROOTEGOED JA, BAARENDS WM, THEMMENAP (1994). Welcome to the family: the anti-müllerian hormone receptor. Mol Cell Endocrinol 100:29-34.

GUO Y, CHENG H, HUANG X, GAO S, YU H, ZHOU R (2005). Gene structure, multiple alternative splicing and expression in gonads of zebrafish Dmrt1. Biochem Biophys Res Commun 330: 950-957.

JOSSO N, LAMARRE I, PICARD JY, BERTA P, DAVIES N, MORICHON N, PESCHANSKI M, JENY R (1993). Anti-Müllerian hormone in early human development. Early Hum Dev 33: 91-99.

KIM KA, ZHAO J, ANDRAMANI S, KAKITANI M, OSHIMA T, BINNERTS ME, ABO A, TOMIZUKA K, FUNK WD (2006). R-spondin proteins: a novel link to the betacatenin activation. Cell Cycle 5: 23-26.

KLÜVER N, PFENNIG F, PALA I, STORCH K, SCHLIEDER M, FROSCHAUER A, GUTZEIT HO, SCHARTL M (2007).Differential expression of anti-Müllerian hormone (amh) and anti-Müllerian hormone receptor type II (amhrll) in the teleost medaka. Dev Dyn 236: 271-281.

KOCER A, PINHEIRO I, PANNETIER M, RENAULT L, PARMA P, RADI O, KIM KA, CAMERINO G, PAILHOUX E (2008). R-spondin1 and Fox/2 act into two distinct 
cellular types during goat ovarian differentiation. BMC DevBiol 8: 36 .

LEI N, HORNBAKER KI, RICE DA, KARPOVA T, AGBOR VA, HECKERT LL (2007). Sex-specific differences in mouse DMRT1 expression are both cell type- and stage-dependent during gonad development. Biol Reprod 77: 466-475.

MARCHAND O, GOVOROUN M, D'COTTA H, MCMEEL O, LAREYRE J, BERNOT A, LAUDET V, GUIGUENY (2000). DMRT1 expression during gonadal differentiation and spermatogenesis in the rainbow trout, Oncorhynchus mykiss. Biochim Biophys Acta 1493: 180-187.

MÜNSTERBERGA, LOVELL-BADGER(1991). Expression of the mouse anti-Müllerian hormone gene suggests a role in both male and female sexual differentiation. Development 113: 613-624.

MURDOCK C, WIBBELS T (2003). Expression of Dmrt1 in a turtle with temperaturedependent sex determination. Cytogenet Genome Res 101: 302-308.

NIEUWKOOP PD, FABER J (Eds.) (1956). Normal tables of Xenopus laevis (Daudin), first ed. Amsterdam, North-Holland.

OREAL E, PIEAU C, MATTEI MG, JOSSO N, PICARD JY, CARREEUSEBE D, MAGRES (1998). Early expression of AMH in chicken embryonic gonads precedes testicular SOX9 expression. Dev Dyn 212: 522-532.

OSAWA N, OSHIMA Y, NAKAMURA M (2005). Molecular cloning of Dmrt1 and its expression in the gonad of Xenopus. Zoolog Sci 22: 681-7.

PARMA P, RADI O, VIDAL V, CHABOISSIER MC, DELLAMBRA E, VALENTINI S, GUERRA L, SCHEDL A, CAMERINO G (2006). R-spondin1 is essential in sex determination, skin differentiation and malignancy. Nat Genet 38: 1304-1309.

PIPREK RP (2009). Molecular mechanisms underlying female sex determination antagonism between female and male pathway. Folia Biolog 57: 105-113.

PIPREK RP, PECIO A, LASKOWSKA-KASZUB K, KLOC M, KUBIAK JZ, SZYMURA JM (2013). Retinoic acid homeostasis regulates meiotic entry in developing anuran gonads and in Bidder's organ through Raldh2 and Cyp26b1 proteins. Mech Dev 130: 613-27. (doi: 10.1016/j.mod.2013.09.001).

RAYMOND CS, SHAMU CE, SHEN MM, SEIFERT KJ, HIRSCH B, HODGKIN J, ZARKOWERD (1998). Evidence for evolutionary conservation of sex-determining genes. Nature 391: 691-695.

RAYMOND CS, KETTLEWELL JR, HIRSCH B, BARDWELL VJ, ZARCOWER D (1999). Expression of Dmrt1 in the genital ridge of mouse and chicken embryos suggests a role in vertebrate sexual development. Dev Biol 215: 208-220.

RODRIGUEZ-MARI A, YAN YL, BREMILLER RA, WILSON C, CANESTRO C, POSTLETHWAIT JH (2005). Characterization and expression pattern of zebrafish anti-Mullerian hormone (Amh) relative to sox9a, sox9b, and cyp19a1a, during gonad development. Gene Expr Patterns 5: 655-667.
ROELANTS K, GOWER DJ, WILKINSON M, LOADER SP, BIJU SD, GUILLAUME K, MORIAU L, BOSSUYT F (2007). Global patterns of diversification in the history of modern amphibians. Proc Natl Acad Sci USA 104: 887-892.

SHIBATAK, TAKASE M, NAKAMURAM (2002). The Dmrt1 expression in sex-reversed gonads of amphibians. Gen Comp Endocrinol 127: 232-241.

SMITH CA, MCCLIVE PJ, WESTERN PS, REED KJ, SINCLAIR AH (1999). Conservation of a sex-determining gene. Nature 402: 601-602.

SMITH CA, SHOEMAKER CM, ROESZLER KN, QUEENJ, CREWSD, SINCLAIRAH (2008). Cloning and expression of R-spondin1 in different vertebrates suggests a conserved role in ovarian development. BMC DevBiol 8: 72-87.

SMITH CA, ROESZLER KN, OHNESORG T, CUMMINS DM, FARLIE PG, DORAN TJ, SINCLAIR AH (2009). The avian Z-linked gene DMRT1 is required for male sex determination in the chicken. Nature 461: 267-271.

STRAUSBERG RL, FEINGOLD EA, GROUSE LH, et al.,2003). Generation and initial analysis of more than 15,000 full-length human and mouse cDNAsequences. Proc Natl Acad Sci USA 99: 16899-903.

TOMASELLI S, MEGIORINI F, DE BERNARDO C, FELICI A, MARROCCO G, MAGGIULLI G, GRAMMATICO B, REMOTTID, SACCUCCI P, VALENITNI F,MAZZILLI MC, MAJORE S, GRAMMATICO P (2008). Syndromic true hermaphroditism due to an R-spondin1 (RSPO1) homozygous mutation. Hum Mutat 29: 220-226.

VIGIER B, TRAN D, LEGEAI L, BÉZARD J, JOSSO N (1984). Origin of anti-Müllerian hormone in bovine freemartin fetuses. $J$ Reprod Fert 70: 473-479.

WEENEN C, LAVEN JS, VON BERGH AR, CRANFIELD M, GROOME NP,VISSER JA, KRAMER P, FAUSER BC, THEMMEN APN (2004). Anti-Müllerian hormone expression pattern in the human ovary: potential implications for initial and cyclic follicle recruitment. Mol Hum Reprod 10: 77-83.

WESTERN PS, HARRY JL, GRAVES JA, SINCLAIR AH (1999). Temperaturedependent sex determination in the American alligator: AMH precedes SOX9 expression. Dev Dyn 216: 411-419.

WITSCHI E (1929). Studies on sex differentiation and determination in amphibians: III. Rudimentary hermaphroditism and Y chromosome Rana temporaria. J Exp Zool 54: 157-223.

YOSHIMOTO S, IKEDA N, IZUTSU Y, SHIBA T, TAKAMATSU N, ITO M (2010). Opposite roles of DMRT1 and its W-linked paralogue, DM-W, in sexual dimorphism of Xenopus laevis: implications of a ZZ/ZW-type sex-determining system. Development 137: 2519-2526.

ZHANG Y, LI F, SUN D, LIU J, LIU N, YU Q (2011). Molecular analysis shows differential expression of R-spondin1 in zebrafish (Danio rerio) gonads. Mol Biol Rep 38: 275-282. 


\section{Further Related Reading, published previously in the Int. J. Dev. Biol.}

Molecular and cellular machinery of gonadal differentiation in mammals.

Piprek RP.

Int J Dev Biol. (2010). 54: 779-86.

http://dx.doi.org/10.1387/ijdb.092939rp

Mammalian and avian embryology at Warsaw University (Poland) from XIX century to the present Andrzej K. Tarkowski, Marek Maleszewski, Teresa Rogulska, Maria A. Ciemerych and Ewa Borsuk Int. J. Dev. Biol. (2008) 52: 121-134

http://dx.doi.org/10.1387/ijdb.072376at

P450 aromatase expression in the temperature-sensitive sexual differentiation of salamander (Hynobius retardatus) gonads.

Natsuko Sakata, Yoichiro Tamori And Masami Wakahara

Int. J. Dev. Biol. (2005). 49: 417-425

http://dx.doi.org/10.1387/ijdb.041916ns

Determination of the sensitive stages for gonadal sex-reversal in Xenopus laevis tadpoles. Villalpando I and Merchant-Larios $\mathrm{H}$ Int J Dev Biol. (1990). 34: 281-285.

Temperature sex-reversal in amphibians and reptiles.

Dournon C, Houillon C and Pieau C

Int J Dev Biol. (1990) 34: 81-92.

Primordial germ cell proliferation in the salamander Pleurodeles waltl: genetic control before gonadal differentiation.

Dournon C, Demassieux C, Durand D, Lesimple M.

Int J Dev Biol. (1989) 33: 477-485.

5 yr ISI Impact Factor $(2011)=2.959$

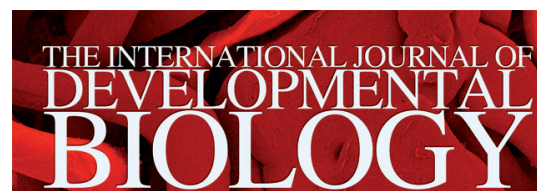

Volume 57 Nos. 2/3/4

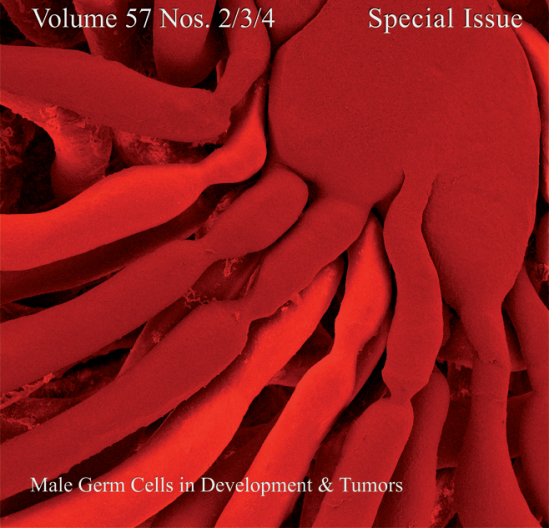

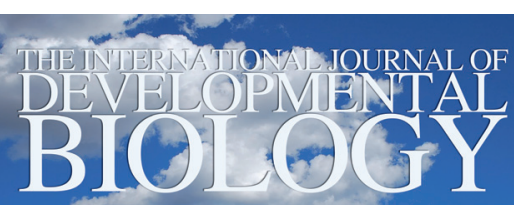

Volume 56 Nos. 10/11/12 Special Issue

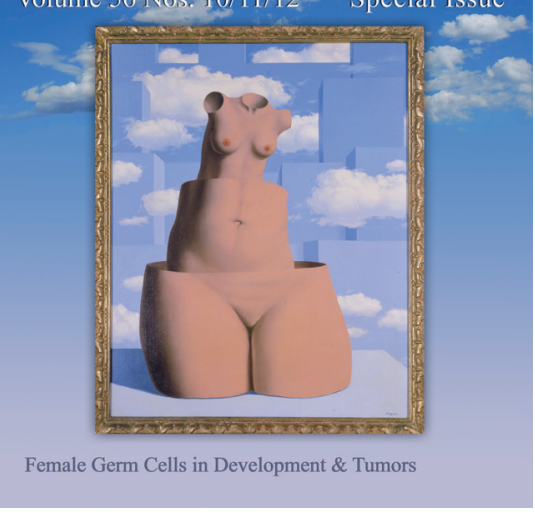

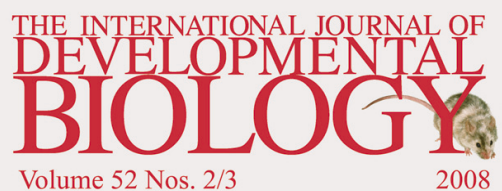

Volume 52 Nos. $2 / 3$ 2008
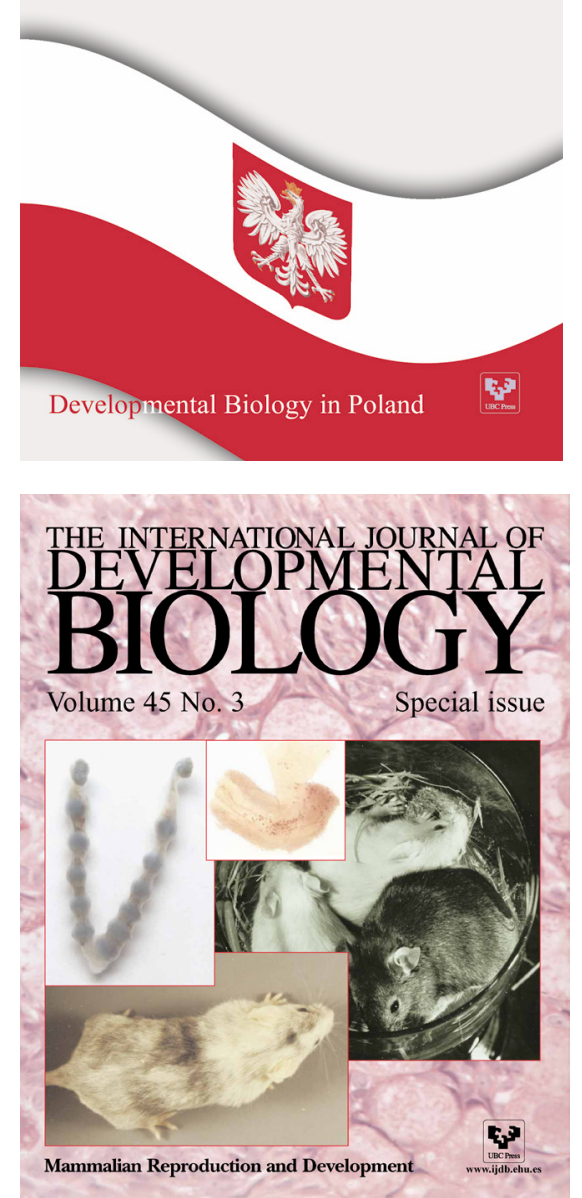